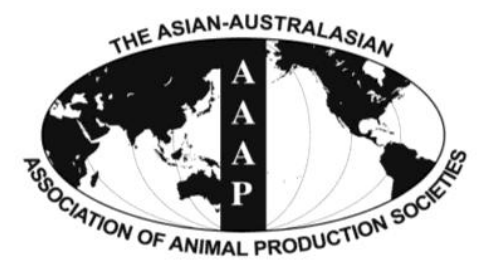

Asian-Aust. J. Anim. Sci.

Vol. 25, No. 5 : 701 - 707

May 2012

www.ajas.info

http://dx.doi.org/10.5713/ajas.2011.11377

\title{
Effects of Immune Stress on Performance Parameters, Intestinal Enzyme Activity and mRNA Expression of Intestinal Transporters in Broiler Chickens
}

\author{
Y. Feng ${ }^{1,2, a}$, X. J. Yang ${ }^{1, a}$, Y. B. Wang ${ }^{1}$, W. L. Li ${ }^{1}$, Y. Liu ${ }^{1}$, R. Q. Yin ${ }^{1}$ and J. H. Yao ${ }^{1, *}$ \\ ${ }^{1}$ College of Animal Science and Technology, Northwest A \& F University, Shaanxi, Yangling 712100, China
}

\begin{abstract}
Immune stress is the loss of immune homeostasis caused by external forces. The purpose of this experiment was to investigate the effects of immune stress on the growth performance, small intestinal enzymes and peristalsis rate, and mRNA expression of nutrient transporters in broiler chickens. Four hundred and thirty-two 1-d-old broilers (Cobb500) were randomly assigned to four groups for treatment; each group included nine cages with 12 birds per cage. Group 1 = no vaccine (NV); Group $2=$ conventional vaccine $(\mathrm{CV})$; group 3 = lipopolysaccharide (LPS)+conventional vaccine (LPS); group 4 = cyclophosphamide (CYP)+conventional vaccine (CYP). The results demonstrated that immune stress by LPS and CYP reduced body weight gain (BWG), feed intake (FI), small intestine peristalsis rate and $\operatorname{sgA}$ content in small intestinal digesta $(\mathrm{p}<0.05)$. However, the feed conversion ratio (FCR) remained unchanged during the feeding period. LPS and CYP increased intestinal enzyme activity, relative expression of SGLT-1, CaBP-D28k and L-FABP mRNAs ( $\mathrm{p}<0.05)$. LPS and CYP injection had a negative effect on the growth performance of healthy broiler chickens. The present study demonstrated that NV and CV could improve growth performance while enzyme activity in small intestine and relative expression of nutrient transporter mRNA of NV and CV were decreased in the conditions of a controlled rational feeding environment. It is generally recommended that broilers only need to be vaccinated for the diseases to which they might be exposed. (Key Words: Broilers, Gene Expression, Immune Stress, Intestine Enzyme)
\end{abstract}

\section{INTRODUCTION}

It is apparent that many factors can influence the immune response of an animal under stress. Stress can suppress, enhance or have no effect on the immune response of an animal. There are many interacting factors influencing the immunological response of an animal under stress, these include stressor types (psychological vs physiological vs physical), duration of stressor (chronic vs acute), genetics, age, and immune status. Some factors in the homeostasis of broilers directly or indirectly affect their immune status, and immunosuppression induced by stress is manifested by failures in vaccination and increased morbidity and mortality of flocks (Shini et al., 2010). Vaccinations are considered necessary to reduce the

\footnotetext{
* Corresponding Author: Junhu Yao. Tel: +86-29-87092102, Fax: +86-29-87092164, E-mail: yaojunhu2004@ sohu.com

2 Department of Life Science, Shanxi Agricultural University, Taigu 030801, China.

a These authors contribute equally to this work. Submitted Oct. 17, 2011; Accepted Jan. 11, 2012; Revised Feb. 13, 2012
}

mortality rate that occurs in modern poultry production. However, immunizations have sometimes been administered in large doses at a high frequency and improper vaccination may lead to immune stress. Studies have demonstrated that stress could affect the intestinal function in animals (Apajalathi and Kettunen, 2003; Teo and Tan, 2007; Rajkumar et al., 2011; Wilkinson et al., 2011) and furthermore disturb the absorption of nutrients (Garriga et al., 2006; Jacobi et al., 2006; Albin et al., 2007). The activities of digestive enzymes are such important factors affecting the absorption and utilization of nutrients in the alimentary tract that they are often used to indicate the intestine function of nutrient absorption. Heat stress causes metabolic and physiological changes in the intestinal transport of glucose through the increase of SGLT1 (Carriga et al., 2006). The effects of stress on the intestinal nutrient absorption in animals may be reflected in two ways. One is nonspecific, in which the absorption of nutrients is affected by the changes of digestive enzymes and intestinal peristalsis rate (Tsukada et al., 2002); the other is specific, in which the absorption of nutrients is affected by changing 
the expression of transporters particularly of nutrients (Shepherd et al., 2004). Expression of these proteins varies during the development of chickens at different ages (Gilbert et al., 2007; Duarte et al., 2011; Yadgary et al., 2011). Research has shown that the immune response can affect growth performance and enteric diseases in commercial poultry, contribute to losses in productivity, increase mortality, and increase the contamination of products for human consumption (Yang et al., 2011). Previous studies have yielded various results; however, the mechanisms of these phenomena have not yet been fully understood. To our knowledge, few studies on the potential effect on the status of broilers reared under immune stress conditions were available. The aims of this study were to determine the balance between the hypo- and hyper-stress, minimize distress while increasing conditions for eustress.

\section{MATERIALS AND METHODS}

\section{Animals and experimental design}

The experiment was performed as a single-factor trial. Four hundred thirty-two 1-d-old broilers (Cobb500) were randomly assigned to four treatments with nine pens per treatment and twelve birds per pen. The four treatments were control group with no vaccine $(\mathrm{NV})$, conventional vaccine group (CV), lipopolysaccharide injected+ conventional immunization group (LPS), and cyclophosphamide injected+conventional immunization group (CYP). All birds were housed in an environmentally controlled room with an initial room temperature of $34^{\circ} \mathrm{C}$ for the first $5 \mathrm{~d}$ and gradually decreased to $21^{\circ} \mathrm{C}$ by the end of the experiment at the third week. Birds were provided with feed and water ad libitum. The lighting program was $24 \mathrm{~h}$ light for the first day, followed by $18 \mathrm{~h}$ light/ $6 \mathrm{~h}$ dark for the rest of the trial period. All experimental procedures were approved by the Animal Ethics Committee of the Northwest A \& F University.

\section{Chemicals and vaccines}

The chemicals used in this study included LPS from E. coli (L2880, Sigma-Aldrich, Inc., St. Louis, Missouri, USA) and CYP (C0768, Sigma-Aldrich). The vaccines used in this study included infectious bronchitis vaccine (IBH $120)$, the inactivated avian influenza $(\mathrm{AI})$ vaccine $(\mathrm{H} 5 \mathrm{~N} 2$, N28 strain), the live vaccine strain Clone-30 of the Newcastle disease virus (NDV), the combined inactive vaccines for infectious bursal disease and the Newcastle disease (ND-IB), all of them were supplied by Harbin Veterinary Research Institute (Harbin, China).

\section{Growth performance measurement}

Body weight gain (BWG) and feed intake (FI) were recorded based on cage weekly. Mortality was recorded daily and feed conversion ratio (FCR) was corrected according to mortality.

\section{Sample collection}

Six birds with body weight close to the mean from each replicate were killed by cervical dislocation on $\mathrm{d} 21$ and $\mathrm{d}$ 42. The duodenum, jejunum and ileum were weighed. Digesta from the duodenum, jejunum and ileum was put in ice-cold phosphate buffered saline (PBS, pH 7.4). Samples were centrifuged $(13,000 \times \mathrm{g}$ for $5 \mathrm{~min})$ at $4^{\circ} \mathrm{C}$, and supernatant was frozen in a $2 \mathrm{ml}$ eppendorf tube immediately at $-20^{\circ} \mathrm{C}$ until needed. The activities of amylase, lipase and trypsin in the small intestinal digesta were determined using standard kits (Jiancheng Bioengineering Institute, Nanjing, China). Intestinal peristalsis rate was detected according to the method described by Poggioli et al. (1995). The level of digesta SIgA was examined with the chicken IgA ELISA quantitation kit (no. E30-103, Behyl Laboratories Inc., Montgomery, TX, USA) as mentioned by Schuijffel et al. (2005).

\section{RNA extraction and real-time PCR (RT-PCR)}

Total RNA was extracted from individual intestinal tissue (duodenum, jejunum and ileum) using the RNeasy kit (Kim et al., 2010) (Qiagen, Germantown, MD, USA). The samples from small intestine were removed and deposited in a $-80^{\circ} \mathrm{C}$ freezer for further analyses of SGLT1, CaBPD28k and L-FABP. A 20 to $30 \mathrm{mg}$ aliquot of each sample was weighed and kept on dry ice until homogenization according to manufacturer's recommendation. In the extraction, RNA was eluted by rinsing the column membrane twice with $50 \mu$ of RNase-free water. Total RNA concentration was determined by optical density (OD) 260 (NanoDrop-1000, Thermo Fisher Scientific, Waltham, MA, USA), and RNA purity was verified by $\mathrm{OD}_{260} / \mathrm{OD}_{280}$ value and formaldehyde-agarose gel electrophoresis. The first strand cDNA was stored at $-20^{\circ} \mathrm{C}$. The relative abundance of transporter mRNA was assayed by quantitative RT-PCR (Table 1).

Gene expression of SGLT-1, CaBP-D28k and L-FABP was assessed by 2-step quantitative RT-PCR using the SYBR Green PCR master mix (Applied Bio Systems Inc., Foster City, CA); mRNA expression was quantified using the iCycler $\mathrm{iQ}^{\mathrm{TM}} 5$ multicolor RT-PCR detection system (Bio-Rad Laboratories, Hercules, CA, USA). A $25 \mu \mathrm{l} \mathrm{PCR}$ mixture was set up as follows: cDNA, $1 \mu \mathrm{l}$; each primer (10 $\mathrm{pmol} / \mathrm{ml}), 1 \mu \mathrm{l} ; 2 \times \mathrm{SYBR}$ Green quantitative PCR master $\operatorname{mix}, 12.5 \mu \mathrm{l}$; and double-distilled water, $10.5 \mu \mathrm{l}$. The temperature cycles were set as following: $95^{\circ} \mathrm{C}$ for $30 \mathrm{~s}$, followed by 40 cycles at $95^{\circ} \mathrm{C}$ for $5 \mathrm{~s}$ and $60^{\circ} \mathrm{C}$ for $30 \mathrm{~s}$. $\mathrm{SYBR}$ green fluorescence was measured at the end of each 
Table1. Primer sequences for PCR amplification of target genes

\begin{tabular}{llcc}
\hline Target genes & Primer sequences & Predicted size (bp) & Genebank accession \\
\hline SGLT1 & S:5'-AGCATTTCAGCATGGTGTGTCTTC-3' & 113 & XM_415247 \\
& AS:5'-GATGCTCCTATCTCAGGGCAGTTC-3' & & NM 204192.1 \\
L-FABP & S:5'-ACTGGCTCCAAAGTAATGACCAATG-3' & 163 & NM 205513.1 \\
CaBP-D28k & AS:5'-TGTCTCCGTTGAGTTCGGTCAC-3' & & \\
\multirow{3}{*}{-Actin } & S:5'-TTGGCACTGAAATCCCACTGAA-3' & & NM_205518 \\
& AS:5'-CATGCCAAGACCAAGGCTGA-3' & 86 & \\
\hline
\end{tabular}

cycle. The melting curve was recorded at $60^{\circ} \mathrm{C}$. All primer concentrations were optimized before actual runs. All measurements were carried out in triplicate to obtain the average values. Expression of SGLT-1, CaBP-D28k, and L-FABP mRNAs from different parts of small intestine was calculated by the $2^{-\Delta \Delta C t}$ method (Livak and Schmittgen, 2001).

\section{Statistical analysis}

Means of replicate were used as the experimental unit for statistical analysis. Data were subjected to one-way ANOVA analysis for the differences between the four groups using SAS software (SAS Institute Inc., Cary, North Carolina, USA, 2002). Differences between means at $\mathrm{p}<$ 0.05 were considered to be statistically significant.

\section{RESULTS}

\section{Performance parameters}

The effect of different types of immune stress on feed intake (FI), body weight gains (BWG) and the feed conversion ratio (FCR) is presented in Table 2. No differences were observed in FI and BWG between NV group and CV group ( $>>0.05)$. However, compared with NV, the BWG decreased significantly in the chickens that had been treated with LPS or CYP $(\mathrm{p}<0.05$ and $\mathrm{p}<0.01)$, and the
FI decreased significantly in the chickens that had been treated with LPS. The FCR showed no significant difference among the four groups $(\mathrm{p}>0.05)$.

\section{Measurements of organ relative weight, enteric enzyme and intestinal peristaltic rate}

Relative weight indices of duodenum and jejunum in $\mathrm{NV}$ group were higher than that in LPS group on $\mathrm{d} 21$ $(p<0.05)$. There was no significant difference in the duodenum, jejunum and ileum weight indices on $\mathrm{d} 42$ (Table 3).

As shown in Table 4, the amylase and lipase of jejunum and ileum in CYP treatment were higher compared with the NV and CV treatments on $\mathrm{d} 21$ and $42(\mathrm{p}<0.05$ and $\mathrm{p}<0.01)$, while the trypsin activity in the small intestine was not significantly different during the whole period ( $p>0.05)$. The intestinal peristalsis rate and sIgA content in NV group were significantly higher than those in LPS and CYP groups $(\mathrm{p}<0.01)$ (Table 5).

\section{Effects of stress on the expression of SGLT1, CaBP- D28k and L-FABP mRNAs in small intestine}

The mRNA levels of related genes in the small intestine are shown in Table 6. The relative expression of SGLT-1, CaBP-D28k and L-FABP mRNAs in the three parts of small intestine in the LPS and CYP groups was significantly or

Table 2. Effect of different immune stressors on growth performance in broilers ${ }^{1}$

\begin{tabular}{|c|c|c|c|c|c|c|c|}
\hline \multirow{2}{*}{ Item $^{2}$} & \multirow{2}{*}{ Weeks } & \multicolumn{4}{|c|}{ Treatments } & \multirow{2}{*}{ SEM $^{1}$} & \multirow{2}{*}{$\mathrm{p}$ value } \\
\hline & & NV & $\mathrm{CV}$ & LPS & CYP & & \\
\hline \multirow[t]{3}{*}{ BWG (kg/bird) } & $1-3$ & 0.70 & 0.69 & 0.64 & 0.68 & 0.010 & 0.166 \\
\hline & $4-6$ & $1.53^{\mathrm{d}}$ & $1.44^{\mathrm{c}}$ & $1.37^{\mathrm{a}}$ & $1.41^{\mathrm{b}}$ & 0.015 & 0.001 \\
\hline & $1-6$ & $2.23^{\mathrm{c}}$ & $2.13^{\mathrm{b}}$ & $2.01^{\mathrm{a}}$ & $2.09^{\mathrm{b}}$ & 0.022 & 0.001 \\
\hline \multirow[t]{3}{*}{ FI (kg/bird) } & $1-3$ & 0.90 & 0.90 & 0.91 & 0.89 & 0.659 & 0.355 \\
\hline & $4-6$ & $2.90^{\mathrm{b}}$ & $2.79^{\mathrm{ab}}$ & $2.69^{\mathrm{a}}$ & $2.70^{\mathrm{ab}}$ & 0.152 & 0.026 \\
\hline & $1-6$ & $3.80^{\mathrm{b}}$ & $3.69^{\mathrm{ab}}$ & $3.59^{\mathrm{a}}$ & $3.60^{\mathrm{a}}$ & 0.329 & 0.004 \\
\hline \multirow[t]{3}{*}{ FCR } & $1-3$ & 1.29 & 1.31 & 1.41 & 1.32 & 0.031 & 0.418 \\
\hline & $4-6$ & 1.89 & 1.93 & 1.97 & 1.93 & 0.032 & 0.103 \\
\hline & $1-6$ & 1.59 & 1.62 & 1.69 & 1.63 & 0.009 & 0.184 \\
\hline
\end{tabular}

${ }^{1}$ Each value represents the mean of 9 replicates for each treatment. ${ }^{2} \mathrm{BWG}=$ Body weight gain; FI $=$ Feed intake; FCR $=$ Feed conversion ratio. ${ }_{\text {a,b,c,d }}$ Means within the same column with different superscripts are significantly different $(\mathrm{p}<0.05)$.

$\mathrm{NV}=$ No vaccine $\mathrm{CV}=$ Conventional vaccine LPS $=$ Lipopolysaccharide CYP = Cyclophosphamide . 
Table 3. Effects of immunity stress on small intestinal index in broilers $(\mathrm{mg} / \mathrm{g})$

\begin{tabular}{|c|c|c|c|c|c|c|c|}
\hline \multirow{2}{*}{ Day } & \multirow{2}{*}{ Item } & \multicolumn{4}{|c|}{ Treatments } & \multirow{2}{*}{ SEM $^{1}$} & \multirow{2}{*}{$\mathrm{p}$ value } \\
\hline & & $\mathrm{NV}$ & $\mathrm{CV}$ & LPS & CYP & & \\
\hline \multirow[t]{3}{*}{$21 \mathrm{~d}$} & Duodenum & $0.95^{\mathrm{b}}$ & $0.90^{\mathrm{b}}$ & $0.84^{\mathrm{a}}$ & $0.86^{\mathrm{ab}}$ & 0.015 & 0.006 \\
\hline & Jejunum & $1.34^{\mathrm{b}}$ & $1.21^{\mathrm{b}}$ & $1.05^{\mathrm{a}}$ & $1.17^{\mathrm{ab}}$ & 0.026 & 0.005 \\
\hline & Ileum & 1.05 & 1.10 & 1.26 & 1.19 & 0.039 & 0.232 \\
\hline \multirow[t]{3}{*}{$42 \mathrm{~d}$} & Duodenum & 0.54 & 0.51 & 0.56 & 0.48 & 0.014 & 0.383 \\
\hline & Jejunum & 1.44 & 1.31 & 1.29 & 1.12 & 0.046 & 0.281 \\
\hline & Ileum & 1.15 & 1.00 & 1.10 & 1.00 & 0.045 & 0.720 \\
\hline
\end{tabular}

${ }^{1}$ Each value represents the mean of 9 replicates for each treatment.

${ }^{a, b}$ Means within the same row column with different superscripts are significantly different $(\mathrm{p}<0.05)$.

$\mathrm{NV}=$ No vaccine $; \mathrm{CV}=$ Conventional vaccine LPS $=$ Lipopolysaccharide $; \mathrm{CYP}=$ Cyclophosphamide .

Table 4. Effects of immunity stress on digestive enzyme activity in small intestinal digesta $(\mathrm{U} / \mathrm{mg})$

\begin{tabular}{|c|c|c|c|c|c|c|c|c|}
\hline \multirow{2}{*}{ Enzyme } & & \multirow{2}{*}{ Item } & \multicolumn{4}{|c|}{ Treatments } & \multirow{2}{*}{ SEM $^{1}$} & \multirow{2}{*}{$\mathrm{p}$ value } \\
\hline & & & $\mathrm{NV}$ & $\mathrm{CV}$ & LPS & CYP & & \\
\hline \multirow[t]{9}{*}{$21 \mathrm{~d}$} & Amylase & Duodenum & 187.91 & 140.30 & 220.59 & 233.52 & 15.237 & 0.147 \\
\hline & & Jejunum & $180.64^{\mathrm{a}}$ & $186.61^{\mathrm{a}}$ & $371.01^{\mathrm{b}}$ & $364.16^{\mathrm{b}}$ & 23.460 & 0.001 \\
\hline & & Ileum & $160.85^{\mathrm{a}}$ & $198.49^{\mathrm{ab}}$ & $228.80^{\mathrm{bc}}$ & $282.33^{c}$ & 12.240 & 0.003 \\
\hline & Lipase & Duodenum & $353.00^{\mathrm{a}}$ & $381.51^{\mathrm{a}}$ & $654.03^{\mathrm{b}}$ & $563.74^{\mathrm{ab}}$ & 38.192 & 0.027 \\
\hline & & Jejunum & $459.67^{\mathrm{a}}$ & $616.91^{\mathrm{bc}}$ & $628.85^{\mathrm{bc}}$ & $744.96^{\mathrm{c}}$ & 27.481 & 0.008 \\
\hline & & Ileum & $416.65^{\mathrm{a}}$ & $510.35^{\mathrm{ab}}$ & $625.65^{\mathrm{bc}}$ & $708.08^{c}$ & 28.987 & 0.004 \\
\hline & Trypsin & Duodenum & 79.15 & 75.70 & 80.94 & 86.61 & 1.558 & 0.284 \\
\hline & & Jejunum & 85.23 & 90.92 & 101.34 & 99.64 & 1.913 & 0.460 \\
\hline & & Ileum & 82.30 & 87.18 & 93.24 & 95.42 & 3.647 & 0.444 \\
\hline \multirow[t]{9}{*}{$42 \mathrm{~d}$} & Amylase & Duodenum & 130.77 & 127.15 & 137.17 & 149.59 & 8.026 & 0.811 \\
\hline & & Jejunum & $131.18^{\mathrm{a}}$ & $151.62^{\mathrm{ab}}$ & $194.21^{\mathrm{bc}}$ & $213.94^{c}$ & 9.148 & 0.006 \\
\hline & & Ileum & $119.61^{\mathrm{a}}$ & $174.98^{\mathrm{ab}}$ & $188.33^{\mathrm{b}}$ & $193.73^{\mathrm{b}}$ & 11.552 & 0.045 \\
\hline & Lipase & Duodenum & 188.53 & 196.47 & 264.74 & 298.66 & 16.000 & 0.084 \\
\hline & & Jejunum & $339.01^{\mathrm{a}}$ & $361.93^{\mathrm{a}}$ & $670.34^{\mathrm{b}}$ & $627.05^{\mathrm{b}}$ & 35.595 & 0.001 \\
\hline & & Ileum & $233.08^{a}$ & $305.66^{\mathrm{ab}}$ & $362.42^{\mathrm{bc}}$ & $415.50^{c}$ & 21.731 & 0.025 \\
\hline & Trypsin & Duodenum & 147.31 & 152.54 & 157.68 & 168.43 & 5.563 & 0.656 \\
\hline & & Jejunum & 134.03 & 138.59 & 161.92 & 173.90 & 6.006 & 0.241 \\
\hline & & Ileum & 118.38 & 143.89 & 152.47 & 160.74 & 7.590 & 0.213 \\
\hline
\end{tabular}

${ }^{1}$ Each value represents the mean of 9 replicates for each treatment.

${ }^{\mathrm{a}, \mathrm{b}}$ Means within the same column with different superscripts are significantly different $(\mathrm{p}<0.05)$.

$\mathrm{NV}=$ No vaccine $; \mathrm{CV}=$ Conventional vaccine LPS $=$ Lipopolysaccharide $; \mathrm{CYP}=\mathrm{Cyclophosphamide}$.

numerically up-regulated in comparison to $\mathrm{CV}$ and $\mathrm{NV}$ groups $(\mathrm{p}<0.05)$.

\section{DISSCUSSION}

Our results showed that immune stress decreased the FI and BWG of chickens (Table 2). It was reported that immune stress may decrease the growth performance of broilers (Eid et al., 2003; Lin et al., 2004; Virden et al., 2007; Star et al., 2008; Rajapakse et al., 2010). The depressed growth performance might be explained by which immune stress is the immuno-modulator and allocates nutrients toward immune response.

Dudley et al. (1998) observed that dietary restriction leads to a decrease in intestinal protein synthesis with concomitant lowering of intestinal weight. Thermal stress caused a consistent increase in amylase activity in broilers, which could result in a significant increase in starch hydrolysis (Osman et al., 1983). Other studies, however, reported that thermal stressed birds had a higher enzymatic activity (Routman et al., 2003). Furthermore, compared to birds fed with control diets, birds with early feed restriction and exogenous protease and amylase supplementation have increased maltase, lipase, and trypsin immediately after the restriction period (Pinheiro et al., 2004). In fact, birds subjected to feed restriction will increase intestinal absorption, and the gastrointestinal tract will be spared the effect of restriction on weight that affects other organs and 
Table 5. Effects of immunity stress on intestinal motility and digesta $\operatorname{SIgA}$ in broilers

\begin{tabular}{|c|c|c|c|c|c|c|}
\hline \multirow{2}{*}{ Item } & \multicolumn{4}{|c|}{ Treatments } & \multirow{2}{*}{ SEM $^{1}$} & \multirow{2}{*}{$\mathrm{p}$ value } \\
\hline & $\mathrm{NV}$ & $\mathrm{CV}$ & LPS & CYP & & \\
\hline $21 \mathrm{~d}$ peristalsis rate $(\%)$ & $0.662^{\mathrm{c}}$ & $0.624^{\mathrm{c}}$ & $0.532^{\mathrm{a}}$ & $0.586^{\mathrm{b}}$ & 0.017 & 0.001 \\
\hline $21 \mathrm{~d}$ sIgA content $(\mathrm{mg} / \mathrm{g})$ & $472.00^{\mathrm{c}}$ & $458.00^{\mathrm{c}}$ & $420.76^{\mathrm{b}}$ & $356.37^{\mathrm{a}}$ & 3.570 & 0.001 \\
\hline $42 \mathrm{~d}$ sIgA content $(\mathrm{mg} / \mathrm{g})$ & $464.15^{\mathrm{b}}$ & $457.70^{\mathrm{b}}$ & $428.24^{\mathrm{a}}$ & $387.23^{\mathrm{a}}$ & 6.277 & 0.001 \\
\hline
\end{tabular}

${ }^{1}$ Each value represents the mean of 9 replicates for each treatment.

${ }^{\mathrm{a}, \mathrm{b}, \mathrm{c}}$ Means within the same row with different superscripts are significantly different $(\mathrm{p}<0.05)$

$\mathrm{NV}=$ No vaccine $; \mathrm{CV}=$ Conventional vaccine LPS $=$ Lipopolysaccharide $; \mathrm{CYP}=\mathrm{Cyclophosphamide}$.

the BWG (Pinheiro et al., 2004). These responses depend on the age of animal and the duration of the restriction period (Casirola et al., 1997; Ferraris et al., 2001). These results may indicate the adaptation of the enzymatic response to immune stress, the higher enzyme activity may have been stimulated by the presence of feed in the gastrointestinal tract for a longer time due to a slower rate of feed passage through the gastrointestinal tract (Barash et al., 1992). Moreover, some investigators e.g. Lessire et al. (1990) observed that feed restriction tended to improve protein, fat, and starch digestibilities irrespective of the diet. However, slower movement speed can increase the chyme residence time in the gut and help nutrient absorption. The current research demonstrated that the effect of immune stress on chickens increased the stress stimulation in the intestinal tract, which might lead to the increased production of intestinal amylase and lipase enzymes in the LPS and CYP groups.
The intestine is relatively enriched with cells actively secreting $\operatorname{Ig} \mathrm{A}$, and $\operatorname{sIg}$ As from the lamina propria of villi in the duodenum and jejunum, and Peyer's patches are important components of intestinal mucosal immunity (Mestecky et al., 1987). Mucosal immunity is an important part of the humoral immunity. Secretory $\operatorname{IgA}$ is the most prominent antibody present at mucosal surfaces, and is the factor of mucosal immunity that provides passive immunoprotection against invading pathogens in the gastrointestinal tract. The results of this study showed that injection with LPS and CYP could decrease sIgA content compared with the NV group. This implies that LPS and CYP may impair the humoral immune system, which led to small intestinal mucosal lesions.

Nutrient transporters play a critical role in the absorption of luminal substrate. In the small intestine of animals, SGLT1 is the key factor that affects absorption of glucose in the small intestine (Kellett, 2001; Wood and

Table 6. Effects of immunity stress on the relative expression of SGLT1, CaBP-D28k and L-FABP mRNAs in the different parts of intestine

\begin{tabular}{|c|c|c|c|c|c|c|c|c|}
\hline \multirow{2}{*}{ Day } & \multirow{2}{*}{ Gene name } & \multirow{2}{*}{ Item } & \multicolumn{4}{|c|}{ Treatments } & \multirow{2}{*}{$\mathrm{SEM}^{1}$} & \multirow{2}{*}{$\mathrm{p}$ value } \\
\hline & & & $\mathrm{NV}$ & $\mathrm{CV}$ & LPS & CYP & & \\
\hline \multirow[t]{9}{*}{$21 \mathrm{~d}$} & SGLT1 & Duodenum & $0.89^{\mathrm{a}}$ & $1.04^{\mathrm{a}}$ & $2.02^{\mathrm{b}}$ & $2.64^{\mathrm{b}}$ & 0.664 & 0.006 \\
\hline & & Jejunum & $0.98^{\mathrm{a}}$ & $0.99^{\mathrm{a}}$ & $1.33^{\mathrm{ab}}$ & $1.58^{\mathrm{b}}$ & 0.397 & 0.008 \\
\hline & & Ileum & 0.81 & 0.78 & 1.02 & 1.01 & 0.477 & 0.380 \\
\hline & CaBP-D28k & Duodenum & 1.12 & 0.84 & 1.17 & 1.89 & 0.124 & 0.068 \\
\hline & & Jejunum & $1.02^{\mathrm{ab}}$ & $0.93^{\mathrm{a}}$ & $1.40^{\mathrm{b}}$ & $1.45^{\mathrm{b}}$ & 0.174 & 0.002 \\
\hline & & Ileum & 0.87 & 0.97 & 1.38 & 1.54 & 0.953 & 0.099 \\
\hline & L-FABP & Duodenum & $1.00^{\mathrm{a}}$ & $0.90^{\mathrm{a}}$ & $1.65^{\mathrm{c}}$ & $1.41^{\mathrm{b}}$ & 0.777 & 0.001 \\
\hline & & Jejunum & 0.86 & 0.66 & 1.22 & 1.32 & 0.951 & 0.131 \\
\hline & & Ileum & $1.03^{\mathrm{a}}$ & $1.21^{\mathrm{ab}}$ & $2.26^{\mathrm{c}}$ & $1.95^{\mathrm{bc}}$ & 0.182 & 0.007 \\
\hline \multirow[t]{9}{*}{$42 \mathrm{~d}$} & SGLT1 & Duodenum & $1.42^{\mathrm{b}}$ & $0.73^{\mathrm{a}}$ & $1.60^{\mathrm{c}}$ & $1.97^{\mathrm{c}}$ & 0.137 & 0.004 \\
\hline & & Jejunum & $0.78^{\mathrm{a}}$ & $0.92^{\mathrm{ab}}$ & $1.50^{\mathrm{c}}$ & $1.29^{\mathrm{bc}}$ & 0.893 & 0.040 \\
\hline & & Ileum & 0.84 & 0.95 & 1.22 & 1.05 & 0.660 & 0.400 \\
\hline & CaBP-D28k & Duodenum & $1.24^{\mathrm{ab}}$ & $0.99^{\mathrm{a}}$ & $2.31^{\mathrm{c}}$ & $1.85^{\mathrm{bc}}$ & 0.157 & 0.006 \\
\hline & & Jejunum & $1.33^{\mathrm{a}}$ & $1.14^{\mathrm{a}}$ & $2.46^{\mathrm{b}}$ & $2.40^{\mathrm{b}}$ & 0.178 & 0.001 \\
\hline & & Ileum & 1.06 & 1.06 & 1.85 & 1.96 & 0.138 & 0.065 \\
\hline & L-FABP & Duodenum & $1.14^{\mathrm{ab}}$ & $0.85^{\mathrm{a}}$ & $1.96^{\mathrm{b}}$ & $2.02^{\mathrm{b}}$ & 0.176 & 0.050 \\
\hline & & Jejunum & $1.28^{\mathrm{ab}}$ & $0.82^{\mathrm{a}}$ & $1.86^{\mathrm{bc}}$ & $2.10^{\mathrm{c}}$ & 0.155 & 0.020 \\
\hline & & Ileum & 1.27 & 0.81 & 1.31 & 1.53 & 0.106 & 0.087 \\
\hline
\end{tabular}

${ }^{1}$ Each value represents the mean of 9 replicates for each treatment.

${ }^{\mathrm{a}, \mathrm{b}, \mathrm{c}}$ Means within the same row with different superscripts are significantly different $(\mathrm{p}<0.05)$.

$\mathrm{NV}=$ No vaccine $; \mathrm{CV}=$ Conventional vaccine LPS $=$ Lipopolysaccharide $; \mathrm{CYP}=$ Cyclophosphamide . 
Frayhum, 2003). A previous study showed that glucocorticoids released during stress periods induce the expression of glucocorticoid regulated kinase, which enhances glucose transportation by increasing SGLT1 abundance in the cell membrane (Carriga et al., 2006). Gilbert et al. (2007) also observed an increase in mRNA abundance of SGLT1 in feed restricted chickens. SGLT1 has the unique ability to transport glucose against its concentration gradient, and it is considered the major pathway for glucose assimilation in the small intestine. Thus, a lower luminal sugar concentration than that in blood during feed restriction may cause the increase in this transporter, due to its important role in the assimilation of glucose. Calcium is absorbed in the duodenum and jejunum by calcium-binding protein $(\mathrm{CaBP})$, which is regulated by a $28 \mathrm{KDa} 1,25(\mathrm{OH})-\mathrm{D}_{3}$ protein $(\mathrm{CaBP}-\mathrm{D} 28 \mathrm{k})$ (Craviso et al., 1987). Two types of fatty acid binding protein (FABP) are found in intestinal epithelium, i. e. intestinal FABP (I-FABP) and liver FABP (L-FABP) (Banaszak et al., 1994). I-FABP participates in the uptake of long-chain fatty acids from digesta in the small intestine into intestinal epithelial cells, and L-FABP transports fatty acids from the cells to the tissues (Prows et al., 1995). In the present study, the increasing demand for energy causes changes in the intestinal epithelium and gene expression of nutrient transporters. The upregulated expression of CaBP-D28k and L-FABP genes in stressed birds may be related to an increased intestinal absorptive function due to immune stress. The increased expression of nutrient transporter mRNA during stress is likely to be a compensation for the loss of absorptive area in the small intestine.

It can be concluded that broilers with $\mathrm{NV}$ or $\mathrm{CV}$ can achieve higher growth performance in a controlled, rational feeding environment, while immune stress can interrupt the homeostasis of the intestine and impair intestinal mucosal immune function. However increased enzyme and mRNA expression in chickens under stress might compensate for the nutrient consumption by the system immune responses or basic metabolic requirements. Extra vaccinating will cost extra growth. This study provides some details about the relationship between immune stress and nutrient partition.

\section{ACKNOWLEDGEMENTS}

The authors are grateful to the support from the Science \& Technological Projects of Shaanxi Province, China (2010ZDGC-02, 2011KTCQ02-02), and National Natural Science Foundation of China (No.31001017 and No.31172223).

\section{REFERENCES}

Albin, D. M., J. E.Wubben, J. M. Rowlett, K. A. Tappenden and R.
A. Nowak. 2007. Changes in small intestinal nutrient transport and barrier function after lipopolysaccharide exposure in two pig breeds. J. Anim. Sci. 85:2517-2523.

Apajalathi, J. and A. Kettunen. 2003. Analysis and dietary modulation of the microbial community in the avian gastrointestinal tract. In: Proceedings of the 26th Technical Turkey Conference, Turkeys Magazine, 49-55.

Banaszak, L., N. Winter and Z. Xu. 1994. Lipid-binding protein: a family of fatty acid and retinoid transport protein. Adv. Protein Chem. 45:89-151.

Craviso, G. L., K. P. Garrett and T. L. Clemens. 1987. 1, 25Dihydroxy vitamin $\mathrm{D}_{3}$ induces the synthesis of vitamin $\mathrm{D}$ dependent calcium-binding protein in cultured chick kidney cells. Endocrinology 120:894-902.

Dudley, M. A., L. J. Wykes, A. W. Dudley, Jr., D. G. Burrin, B. L. Nichols, J. Rosenberger, F. Jahoor, W. C. Heird and P. J. Reeds 1998. Parenteral nutrition selectively decreases protein synthesis in the small intestine. Am. J. Physiol. 274:G131-137.

Duarte, C. R. A., M. L. M. Vicentini-Paulino, J. Buratini Jr., A. C. S. Castilho and D. F. Pinheiro. 2011. Messenger ribonucleic acid abundance of intestinal enzymes and transporters in feedrestricted and refed chickens at different ages. Poult. Sci. 90: 863-868.

Eid, Y. Z., A. Ohtsuka and K. Hayashi. 2003. Tea polychenols reduce glucocorticoid induced growth inhibition and oxidative stress in broiler chickens. Br. Poult. Sci. 44:127-132.

Gal-Garber, O., S. J. Mabjeesh, D. Sklan and Z. Uni. 2000. Partial sequence and expression of the gene for and activity of the sodium glucose transporter in the small intestine of fed, starved and refed chickens. J. Nutr. 130:2174-2179.

Garriga, C., R. R. Hunter, C. Amat, J. M. Planas, M. A. Mitchell and M. Moretó. 2006. Heat stress increases apical glucose transport in the chicken jejunum. Am. J. Physiol. Regul. Integr. Comp. Physiol. 290:R195-201.

Gilbert, E. R., H. Li, D. A. Emmerson, K. E. Webb Jr. and E. A. Wong. 2007. Developmental regulation of nutrient transporter and enzyme mRNA abundance in the small intestine of broilers. Poult. Sci. 86:1739-1753.

Jacobi, S. K., N. K. Gabler, K. M. Ajuwon, J. E. Davis and M. E. Spurlock. 2006. Adipocytes, myofibers, and cytokine biology: new horizons in the regulation of growth and body composition. J. Anim. Sci. 84(E-Suppl.):E140-E149.

Kellett, G. L. 2001. The facilitated component of intestinal glucose absorption. J. Physiol. 531:585-595.

Kim, S., K. B. Miska, M. C. Jenkins, R. H. Fetterer, C. M. Cox, L. H. Stuard and R. A. Dalloul. 2010. Molecular cloning and functional characterization of the avian macrophage migration inhibitory factor (MIF). Dev. Comp. Immunol. 34:1021-1032.

Lemmens J. W. T. J. 1995. Nucleic acid levels, cellular activity and growth during the puerulus stage of the Western Pock Lobster (Panulirus Cygnus (George); Decapoda: Palinuridae). J. Exp. Mar. Biol. Ecol. 194:143-156.

Lessire, M. 1990. Effect of feeding technique, ad libitum, dry or wet force feeding on the metabolisable energy values of raw materials for poultry. Br. Poult. Sci. 31:785-793.

Lin, H., E. Decuypere and J. Buyse. 2004. Oxidative stress induced by corticosterone administration in broiler chickens (Gallus gallus domesticus) 1. Chronic exposure. Comp. Biochem. Physiol. 139B:737-744. 
Livak, K. J. and T. D. Schmittgen. 2001. Analysis of relative gene expression data using real-time quantitative PCR and the $2^{-\Delta \Delta \mathrm{CT}}$ method. Methods 25:402-408.

Mestecky, J., C. Czerkinsky, M. W. Russell, T. A. Brown, S. J.Prince, Z. Moldoveanu, S. Jackson, S. M. Michalek and J. R. McGhee. 1987. Induction and molecular properties of secretory and serum $\operatorname{IgA}$ antibodies specific for environmental antigens. Ann. Allergy 59:54-59.

Mitchell, M. A. and A. J. Carlisle. 1992. The effect of chronic exposure to elevated environmental temperature on intestinal morphology and nutrient absorption in the domestic fowl (Gullus domesticus). Comp. Biochem. Physiol. 101A:137-142.

Nasir, A., R. P. Moudgal and N. B. Singh. 1999. Involvement of corticosterone in food intake, food passage time and in vivo uptake of nutrients in the chicken (Gallus domesticus). Br. Poult. Sci. 40:517-522.

Osman, A. M. and N. I. Tanios. 1983. The effect of heat on the intestinal and pancreatic levels of amylase and maltase of laying hens and broilers. Comp. Biochem. Physiol. 75A:563567.

Pinheiro, D. F., V. C. Cruz, J. R. Sartori and M. L. Vicentini Paulino. 2004. Effect of early feed restriction and enzyme supplementation on digestive enzyme activities in broilers. Poult. Sci. 83:1544-1550.

Poggioli, R., A. Benelli, R. Arletti, E. Cavazzuti and A. Bertolini. 1995. K+ channel openers delay intestinal transit and have antidiarrheal activity. Eur. J. Pharmacol. 287:207-209.

Prows, D. R., E. J. Murphy and F. Schroeder. 1995. Intestinal and liver fatty acid-binding proteins differentially affect fatty acid uptake and esterification in L-cell. Lipids 30:907-910.

Rajapakse, J. R. P. V., M. D. P. Buddhika, M. Nagataki, H. Nomura, Y. Watanabe, Y. Ikeue and T. Agatsuma. 2010. Effect of sophy beta-glucan on immunity and growth performance in broiler chicken. J. Vet. Med. Sci. 72:1629-1632.

Rajkumar, U., M. R. Reddy, S. V. R. Rao, K. Radhika and M. Shanmugam. 2011. Evaluation of growth, carcass, immune response and stress parameters in naked neck chicken and their normal siblings under tropical winter and summer temperatures. Asian-Aust. J. Anim. Sci. 24:509-516.

Routman, K. S., L. Yoshida, A. C. Frizzas de Lima, M. Macari and Jr. J. M. Pizauro. 2003. Intestinal and pancreas enzyme activity of broilers exposed to thermal stress. Brazilian J. Poult. Sci. 5:23-27.

Savory, J. 1986. Influence of ambient temperature on feeding activity parameters and digestive function in domestic fowls. Physiol. Behav. 38:353-357.

SAS Institute. 2002. SAS users guide: Statistics. SAS Institute Inc., Cary, NC, USA.
Schuijffel, D. F., P. C. van Empel, A. M. Pennings, J. P. vanPutten and P. J. Nuijten. 2005. Passive immunization of immunesuppressed animals: Chicken antibodies protect against Ornithobacterium rhinotracheale infection. Vaccine 23:34043411.

Shini, S., G. R. Huff, A. Shini and P. Kaiser. 2010. Understanding stress induced immunosuppression: Exploration of cytokine and chemokine gene profiles in chicken peripheral leukocytes. Poult. Sci. 89:841-851.

Shepherd, E. J., P. A. Helliwell, O. J. Mace, E. L. Morgan, N. Patel and G. L. Kellett. 2004. Stress and glucocorticoid inhibit apical Glut2-trafficking and intestinal glucose absorption in rat small intestine. J. Physiol. 560:281-290.

Star, L., B. Kemp, Anker. I. van den and H. K. Parmentier. 2008. Effect of single or combined climatic and hygienic stress in four layer lines: 1. Performance. Poult. Sci. 87:1022-1030.

Teo, A. Y. and H. M. Tan. 2007. Evaluation of the performance and intestinal gut micro flora of broilers fed on corn-soy diets supplemented with Bacillus subtilis PB6 (CloSTAT). J. Appl. Poult. Res. 16:296-303.

Tsukada, F., K. Sawamura, H. Kohno and Y. Ohkubo. 2002. Mechanism of inhibition of small intestinal motility by restraint stress differs from that with norepinephrine treatment in rats. Biol. Pharm. Bull. 25:122-124.

Uni, Z., E. Tako, O. Gal-Garber and D. Sklan. 2003. Morphological, molecular, and functional changes in the chicken small intestine of the late-term embryo. Poult. Sci. 82: 1747-1754.

Virden, W. S., M. S. Lilburn, J. P. Thaxton, A. Corzo, D. Hoehler and M. T. Kidd. 2007. The effect of corticosterone induced stress on amino acid digestibility in Ross broilers. Poult. Sci. 86:338-342.

Wilkinson, K. G. E., R. B. Tee, G. Tomkins and R. Premier. 2011. Effect of heating and aging of poultry littern the persistence of enteric bacteria. Poult. Sci. 90:10-18.

Wilson, E. K., E. W. Pierson, P. Y. Hester, R. L. Adam and W. J. Stadelman. 1980. The effect of high environment temperature on food passage tissue and performance traits of Pekin ducks. Poult. Sci. 59:2322-2330

Wood, S. and P. Frayhum. 2003. Glucose transporters (GLUT and SGLT): expanded families of sugar transport protein. Br. J. Nutr. 89:3-9.

Yang, X. J., W. L. Li, Y. Feng and J. H. Yao. 2011. Effects of immune stress on growth performance, immunity, and cecal microflora in chickens. Poult. Sci. 49:2740-2746.

Yadgary, L., R. Yair and Z. Uni. 2011. The chick embryo yolk sac membrane expresses nutrient transporter and digestive enzyme genes. Poult. Sci. 90:410-416. 